IVAN CUCCO ${ }^{1}-$ MARIA FONTE ${ }^{2}$

LOCAL FOOD AND CIVIC FOOD NETWORKS AS A REAL UTOPIAS PROJECT

Dol: 10.18030/sOCIO.HU.2015EN.22

\title{
ABSTRACT
}

For scholars and activists alike, local food is linked to visions of a more equitable, ethical and sustainable agro-food system. Notwithstanding an apparent unity, local food is mobilized for very different aims including environmental sustainability, the revitalization of rural economies, the reconnection of consumers to agriculture and nature and the promotion of land entitlements for marginalized populations. At the same time, local food has become a crucial element in protectionist and neo-ruralist ideologies that support bounded, defensive spatial strategies. These contradictions point to the limited heuristic value of the 'local food' concept, particularly when decoupled from an explicit attention to the political and power dimensions of the local.

Building upon these considerations, in this article we explicitly focus on the political and transformative dimensions of different local food projects and propose to read local food as a 'real utopia' project whose aim is the transformation of the food economy in the direction of sustainability, social emancipation and social justice. Utilizing the framework developed by E.O. Wright, we look at local food as a diagnosis and critique of the present; as the prefiguration of a more sustainable, just and democratic future; and as a set of transformative strategies that aim at changing the system in the desired direction.

Our analysis suggests that, differently from the oppositional movements of the Fordist era, the local food movement is characterized by its use of interstitial ("ignore the state") and symbiotic ("use the state") strategies. These strategies either seek to establish new economic and social relations at the margins of the neoliberal food economy, or partner with local institutions to consolidate new experiences with food democracy and food justice.

By mobilizing non-ruptural strategies in the service of a real utopian project, local food initiatives are opening up new, enlarged spaces for non-capitalist or post-capitalist economies that constitute the basis for social learning and experimentation of a global more sustainable and just food system. A further step ahead could be constituted by the promotion of a reflexive, more democratic, socially empowering system of governance, able to lead the innovative potential of the food movement to its full expression.

Keywords: local food, alternative food networks, civic food networks, real utopias project, food governance.

1 Adjunct Professor, Graduate School, The American University of Rome

2 Associate Professor, Department of Economics, Management, Institutions, University of Naples Federico II 
IVAN CUCCO - MARIA FONTE

\section{Local Food And Civic Food Networks as a ReAl Utopias Project}

\section{INTRODUCTION: THE DEBATE ON LOCAL FOOD}

The literature on local food, alternative agriculture and civic food networks has grown enormously in recent years. A quick interrogation of Google Scholar for academic articles on 'local food' gives 20,300 results for local food and 3,320 for alternative agriculture ${ }^{3}$. In activist narratives and academic debates, local food is being linked to visions of a more equitable, ethical and sustainable agro-food system. Its alternativeness rests on the connection of food to the territory, i.e. to the natural (agro-ecological) and social context in which food is produced and consumed. As for the agro-ecological conditions, the local food discourse promotes respect for the environment and nature. As for the social context, it emphasizes the inclusion of people who are currently marginalized by the corporate and increasingly financialized food production system. This implies, on the one hand, the protection of small farms and of their knowledge; on the other, a concern for the poor voiced in requests for increased access to a healthy, culturally sound diet.

A variety of practices and movements have gathered under the 'local food' umbrella in both the global North and South. Beyond the widespread diffusion of Farmers' Markets, prominent examples of local food initiatives in the global North include Community Supported Agriculture (CSA), AMAPs (Association pour le Maintien d'une Agriculture Paysanne), Solidarity Purchasing Groups and Food Teams. In Eastern Asia, while a rising awareness of the social and environmental risks associated with major events like the Fukushima nuclear plant accident may lead to a disconnection between the local and the organic, the globalization process brought about by the TPP (Trans-Pacific Partnership) agreement may act as a catalyst for otherwise disconnected experiences related to local food, organic agriculture and Alternative Food Networks (AFNs). In the global South, as well as in many Eastern European and Mediterranean countries, local food initiatives not only propose an alternative to the corporate food system, but also aim at valorising local markets, traditional foods, peasant and subsistence agriculture as forms of 'quiet sustainability' (Smith and Jehlička 2013). Especially in Latin America, local food initiatives are contributing to the elaboration and consolidation of new practices linked to a novel model of agro-ecological development, based on the valorisation of farmers' knowledge and experimentation in opposition to the expert-led model of the science- and technology-intensive GMO agriculture (Altieri, Nicholls 2010).

As the debate advances, the transformative practices and academic discourses that deploy the concept of local food appear far from homogeneous. Different initiatives mobilize the concept of the 'local' for various transformative aims: environmental sustainability (Feenstra 1997, Pretty et al. 2005, Pirog et al. 2001 and 2003, Garnett 2007), the revitalization of rural economies and the reconnection of urban consumers to agriculture 
and nature (Renting et al. 2003, Marsden et al. 2000, Fonte 2008, Brunori et al. 2012); the agro-ecological revolution, especially in Latin America (Altieri and Toledo 2011); advancing land entitlements for marginalized groups in the face of encroaching dispossession in the Global South (McMichael 2014). At the same time, local food is also a crucial element in protectionist and neo-ruralist ideologies promoting bounded, defensive spatial strategies (Hinrichs 2000, Born and Purcell 2006).

These contradictions point out to the limited heuristic value of "local food" as an analytical category, particularly when decoupled from an explicit attention to the political and power dimension of the local, considered in its own right as well as in its multi-scalar interactions. The contribution of a 'reflexive localism' (Goodman, DuPuis and Goodman 2012, Fonte 2013b) and the opening up of food studies to insights from other disciplines, e.g. critical human geography, highlight the importance of politics in places (Hinrichs 2015). In this perspective the 'local' becomes the space for the enactment of a political agenda and the nexus of a political reflection involving the construction of a more equitable and more sustainable food economy (Harris 2009), an emancipatory project leading the way to a transition toward sustainability (Hinrichs 2014).

Building upon these considerations, in this article we explicitly focus on the political and transformative dimensions of different local food projects. To this end, we propose to read local food initiatives as 'real utopias' projects, whose central aim is transforming the food economy in the direction of environmental sustainability, social emancipation and social justice. Looking at local food discourses and movements through the framework of a transition theory offers the advantage of connecting the local food practices to other proposals for emancipatory responses to the disruptive effects of neoliberal capitalism such as participatory budgeting and empowered participatory governance, the social economy of welfare provision, the experience of transition cities, the sharing economy and open-source software.

In the next section we will locate the real utopias project in the realm of transition theories, highlighting its similarities and differences with the multilevel perspective on the socio-technical regime transition (Geels 2005, Geels and Schott 2007) and the social practice theory (Reckvitz 2002, Schatzki 1996). In the remainder of the article we will analyse local food as a 'real utopia', articulating our reading of the literature on local food and civic food networks with the three core dimensions proposed by Wright (2006, 2010): a critique of the dominant food system; a prefiguration of the desirable future food economy and a proposal of strategies for getting there. A discussion and a conclusion will follow, aimed at pleading how a reflexive, social empowered system of governance could scale up and bring to its full potential the transformative potential of civic food networks in direction of a more just and more sustainable food economy.

\section{TRANSITION THEORIES AND THE REAL UTOPIAS PROJECT}

Our interpretation of local food as a heuristic for the transition to sustainability draws upon different theories: the multilevel perspective (MLP), social practice theory, and the 'real utopias' project. Both the MLP and practice theory deal with the problem of how to advance towards more sustainable consumption and production systems; the 'real utopias' perspective is instead fundamentally interested in visions (and practices) that aim at building new institutional architectures that can enhance social emancipation and deepen 
democratic participation.

The MLP (Geels 2005; Geels and Schott 2007) has to date offered the most articulated theory of transition towards (environmental) sustainability of the economic system. It relies on the concept of 'strategic niche management' and sees the achievability of the transformation objectives as a progression from interstitial or symbiotic strategies to the reconfiguration of the entire system in the direction of sustainability. Innovative ideas and solutions emerge and are developed in spaces protected from market competition; in these innovation niches, learning processes are set in motion and new forms of economic and social organization are experimented with. The resulting innovations may be scaled up to system-wide proportions or may be coopted by the dominant system through adequate governance mechanisms, so as to provide a basis for new socio-technical regimes that reconfigure the system as a whole. In some way, interstitial niche innovation may obtain different results as to the degree of system transformation depending on the pressure deriving from landscape (structural, exogenous) variables and the capacity of the new social-technical (niche) solutions to resolve the economic and social contradictions of the dominant regime. Policy recommendations stemming from the MLP literature are primarily related to the governance of the socio-technical regime change, through a mix of tools that may go from networks governance in an early phase of niche stimulation, to regulation, standards, tax and subsidies in later phases, aimed at widespread uptake of the innovation.

Practice theory is concerned not so much with how to govern the necessary changes in the socio-technical structure (which may represent the production side of a sustainable economy), but with how to change social practices that have become routine, especially the social practice of consumption, so as to reach sustainability goals (Reckvitz 2002; Schatzki 1996; Shove et al. 2012). It is a 'social theory' in so much as its unity of analysis is not the single firm or the individual, but specific social practices, routine forms of behaviour constituted by a nexus of interrelated elements of different natures, both material (such as objects and things) and immaterial (competences and meanings). In practice theory the transition to an enhanced sustainable food system may be seen as a challenge to the dominant routine food practices and the foreshadowing of a new practice, based on new norms and understandings, a new material infrastructure and a new agency (Warde 2005; Halkier 2009; Crivitis and Paredis 2013; Fonte 2013a). In this case, the transformation theory is directed at devising policy interventions addressing the systemic challenges of changing social practices in their meanings, material structures and ways of understanding.

Neither the MLP nor PT are concerned with a theory of the new possible institutional architecture of the relationships between State, economic and social power, which may guarantee a more just economy and society. Their main interest lies in the modification of social practices or in the transformation of the sociotechnical system to enhance sustainability and address environmental problems. In the words of Geels et al. (2015: 6):

"Transformation towards new transport, electricity heat or agro-food system and practices are more radical than the solution in the reformist position, but do not necessarily presume the abandonment of capitalism, economic growth or the embrace of frugality".

In this respect, Geels et al. (2015) differentiate the 'reconfiguration position' of MLP and PT proponents 
from the revolutionary 'sustainable consumption and production' position associated with the 'new economics' (Jackson 2009), the 'de-growth approach' (Demaria et al. 2013) or the 'sharing economy' (Rifkin 2014). The reconfiguration position, while accepting that "'green' innovation or practices should not only be environmentally sustainable, but also economically viable and socially acceptable" (Geels et al. 2015: 7), does not aim to simultaneously solve problems of poverty, inequality and democratic accountability. The revolutionary position, on the contrary, suggests that addressing environmental problems requires more fundamental changes in the economic system and a shift to a more egalitarian and equitable society.

In contrast to both the MLP and practice theory, the 'real utopias' project is an explicitly emancipatory social project: 'emancipatory' because it centres on a moral purpose (ending social oppression and the creation of conditions for human flourishing); 'social' because it implies a belief that emancipation depends on the transformation of the social world, not only of the individual or the economy (Wright 2006).

According to Fung and Wright (2003) and Wright (2006; 2010) the 'real utopias project' embraces the tension between dreams and practice. 'Utopia' implies developing visions of alternatives to dominant institutions that embody aspirations for a better world, while 'real' refers to proposing desired alternatives that are viable and achievable. The exploration of 'real utopias' is an integral part of an emancipatory social science with three core tasks:

- Explain why we want to change the present system, i.e. elaborate a diagnosis and critique of existing institutions, according to specified moral principles.

- Explain where we want to go, i.e. envisage viable alternatives to the present social structure,

- Proposing how to get where we want to go, i.e. develop a theory of transformation for realizing the desirable alternatives.

Proposals for transformation need to be desirable, viable and achievable. The achievability of a viable alternative depends "upon the extent to which coherent, compelling strategies can be formulated which both help to create the conditions for implementing alternatives in the future, and have the potential to mobilize the necessary social forces to support that alternative when such conditions occur" (Wright 2006: 99).

In the remainder of this article we will use these three dimensions to articulate our reading of 'local food' as a 'real utopias project' by highlighting how the local food concept is used: (1) as a diagnosis and a critique of the mainstream food system; (2) as the prefiguration of a more sustainable, democratic and just food economy; (3) in order to identify strategies for realizing the desirable alternatives.

\section{LOCAL FOOD AS A CRITIQUE OF THE PRESENT}

'Local food' conveys its critique of the dominant food system through the concept of space. Friedman (1992) was among the first to identify the main problems of the industrial food system (or better, in her words, the Fordist food regime) in terms of 'distance' and 'durability'. Distance has to do with space, intended as both the space of production and the space of consumption. Also, Kloppenburg et al. (1996: 38) refer to distancing as the main challenge in the food system: "If the mitigation of the deleterious effects of distancing is one of 
the central challenges posed by the operation of the global food system, then greater attention to proximity - to that which is relatively near - should be an appropriate response." The pioneering concept of 'foodshed' is conceived exactly as a response able to 'repair and fix' the food system. In a recent paper, Hinrichs (2015: 1) writes: "ideas of 'local' and 'place' have been pressed into service to fix food and link it to a more meaningful somewhere, redressing harms associated with a global neoliberal food and agricultural system".

What then are the harms that the idea of 'proximity' should fix and repair? In the literature on local food, distance has been analysed in a double meaning: geographical and social; these two aspects are different, but interconnected. In its geographical meaning, local food means a critique of the long physical distance food travels 'from farm to fork' in industrialized, consolidated global value chains. Attention to food miles links concerns over food to environmental preoccupations with climate change and emissions of carbon dioxide and other greenhouse gases from transport.

A sharp contrast is drawn between the short chain for local food and the long distance food is required to travel in the conventional, centralized, industrialized food system. In the United States, Pirog and Rasmussen (2008) analysed the transport arrangements for 28 fruits and vegetables to lowa markets via local and conventional food distribution systems and calculated that produce in the conventional system travelled an average of 1,546 miles (about 2,500 kilometres) while by contrast locally sourced food travelled an average of just 44.6 miles (72 kilometres). In the European Union, food consumption's contribution to GHG emission is calculated to be 31 per cent of total consumption (Tukker et al. 2006).

From an economic geography perspective, the relation between urban and rural is also questioned. The rural has always been conceptualized as a provider of labour, goods and services functional to the necessities of the city. From here stems the 'urban bias' (Lipton 1977) of any development vision, which sees agriculture and countryside as subordinated to urban needs. This dichotomized vision of space has now been overcome as food has been legitimated among the 'urban questions', not only through the notion and initiatives of urban agriculture but also through a new awareness of the importance of food for the 'hungry city' (Steel 2013). A new conceptualization of the rural-urban relation through the concepts of foodshed or the food city region aims at overcoming this dichotomy (Morgan et al. 2006, Kloppenburg et al. 1996).

From a social perspective, production processes in the agro-industrial food complex are de-territorialized, placeless and centred around the commodification of food (food from nowhere). According to Patel (2007), the organization of the global food value chain is based on unfair exchange relations which favour big intermediaries (above all the retailing industry) against the interests of agricultural producers and final consumers, with the former not earning a living income and the latter paying too much for food. This leads to great social paradoxes, like the simultaneous presence of overproduction, obesity and food shortages: at the global scale, in 2014750 millions people suffer from hunger (FAO 2015), while 1.9 billion are overweight, of whom 670 million are obese and at risk of illnesses such as diabetes and cardiovascular diseases. According to Kloppenburg et al. (1996: 36) 'distancing disempowers'; because of the physical and social distancing that characterize the global food system, control passes to those who know how to act at a distance: the big corporates and multinationals. 
Attempts to transform the mainstream food system were already in place in the 1960s: organic agriculture was certainly the most important and most widely known among such attempts ${ }^{4}$. But in the 1990s a widespread perception that the organic movement had dropped its alternative / environmental ideological baggage grew up. The organic movement was seen as seduced by multinational retailing firms with the prospect of a mass market (Blythman 2005). Furthermore, organic certification was seen as encouraging nonlocal food consumption, with consequent increases in costs for producers and prices for local consumers. A logic of 'input substitution' leading to 'conventionalisation' was considered to be an increasing trend in the organic movement, and became part of the problems that need to be 'fixed' (Guthman 2003, Buck et al. 1997, Darnhofer et al. 2010). The 'post-organic' (Moore 2006) local food movement shifted therefore its focus to the necessity of bringing consumers back into the food system, re-establishing a connection between the producer and the consumer and addressing the sustainability not only at the point of production, but also in the distribution system of the food chain (Fonte 2010: 6).

LOCAL FOOD AS THE PREFIGURATION OF WHERE WE WANT TO GO: FROM LOCAL AGRICULTURE TO CIVIC FOOD NETWORKS

The transformative horizon of localness is predicated on the re-connection of food to the territory in which it is produced and consumed. Localness articulates different dimensions of proximity: geographical, social, cultural and ecological. It is associated with space and short distance, but also with place, regions and territories as well as with small-scale farms, multifunctional agriculture, quality food, rural livelihoods and sustainable community agriculture. Local food is ultimately about much more than short distance:

The local food movement is about an ethic of food that values reviving small scale, ecological, placebased, and relationship-based food systems... Large corporations peddling junk food are the exact opposite of what this is about. (Severson 2009, in DeLind 2011 D-1)

From a sociological viewpoint local food is place-embedded, the opposite of the placeless food of industrial agriculture. This concept of embeddedness imparts social meaning to notions of place, social meaning to be elaborated by the rural communities inhabiting the 'places' in question. The shortness of local food chains makes it possible to trace the food almost personally to the individual farmer who produced it, enabling relations of trust to be established in the local society. Food production is re-contextualized within the formal and informal social relationships that constitute the basis for community life. Geographical proximity is, then, important because it implies or favours social proximity, i.e. face-to-face interactions between producers and consumers.

Such interactions have a significant impact on rural community life. Local food becomes part of a political project for keeping rural communities alive and constructing local economies which respect natural resources, give attention to cultural and biological diversity, defend the economic sustainability for small farmers and promote social justice and food sovereignty. The place-embeddedness of food may thus be conceived of as local society's resistance strategy against globalisation and neoliberalism (Polanyi 1944) and it comes forward

4 This is not to say that the organic movement was born in the 1960s. It started earlier and at different times in different countries (Reed 2010). 
as a cultural, individual and collective societal response to the commodification-of-everything (Strassen 2003) drive of the neoliberal economy.

Place-embeddedness is, however, not strictly identical with 'localness'. Actually the relation between 'localness' and 'sustainability' has been problematized, both in theory and in practice. The environmental impact of the food economy does not depend only on the distance 'from farm to fork', but also on how food is transported, grown, transformed and prepared. Only a life-cycle analysis of food can yield an accurate assessment of the total volume of gas emissions linked to its production and distribution. The difficulty of establishing well-defined boundaries for the notion of 'locality', taking into account the conditions for the entire life-cycle of production, appears to undermine the usefulness of 'localness' as a category for the analysis of food systems sustainability (Garnet 2007).

Other authors question the relation between localness and 're-embedding'. To use the words of DeLind (2011), we must ask ourselves: 'is local food taking us where we want to go?' Hinrichs (2015) invites us to look at how the distribution of interests and power across different groups of farmers and consumers, as well as across varied organizations and institutions, serves to concentrate or spread the benefits and risks when fastening food to a locality. Hinrichs also suggests to more seriously exploring the effect of fastening food on the flexibility needed to respond to emerging sustainability or health challenges. The concept of 'local trap' (Born and Purcell 2006) wants to highlight the risks implicit in assuming that proximity always results in benefit or repair for environmental impact and social justice.

Finally, localness is a descriptive concept and its limited heuristic value is evident when we want to distinguish a progressive versus a defensive localism or reconcile localism with 'a sense of planet' (Heise 2008) or with a 'global sense of place' (Massey 1994). From these critiques and from the quest for a more reflexive localism the need has emerged to assume more explicitly the concept of 'civic agriculture' (Lyson 2004) and civic values into the conceptualization of local food.

Renting et al. (2012) propose 'Civic Food Networks' (CFNs) as a complementary category to concepts such as 'short food supply chains' and 'local(ized) food systems'. CFNs may better express the processes of change in the agri-food governance mechanisms, showing the increasingly important role of civil society (and to some extent of local and regional administrations) compared to market forces and to the (national) state; they imply a new conception of food citizenship and food democracy and the regeneration of food governance mechanisms. CFNs refer to the network of all actors involved in the local food system that, as ecological citizens, partake of the responsibility for the sustainability of the food economy and endorse the value of food as a commons and a right. CFNs aim to guarantee access (both physical and economic) to sustainable food to all people, individuals and communities. There is no transition to sustainability if sustainable food is for the elite: as a member of the GAS movement in Rome said, a system that guarantees sustainable food only for an elite is unjust, exactly as the industrial food system is and cannot either lead to sustainability (Fonte 2013a).

Finally, sustainability and food democracy are the double challenge that CFNs will have to face. The 'utopian' food economy towards which the CFNs vision aims is a local-based food system, which can endorse civic values like sustainability, but also food as a right, food as a common and food democracy. 


\section{HOW WE GET THERE: TRANSFORMATIVE STRATEGIES}

The local food movement is too heterogeneous to express a single, defined political theory for the transformation of the food system. Different stances within the movement could be enrolled into a reformist, a revolutionary or a reconfiguration position (Geels et al. 2015). Furthermore the 'buy local' prescription is, in itself, not sufficient to trigger a transformation in the desired directions of the food system, let alone of the whole society.

In any case the local food movement is not based on an individual consumer strategy of buying local, as much as on collective strategies for the transformation of the food system. According to the real utopias project, the collective strategies that can move a system in the direction of social emancipation can be classified in three broad categories according to their relationship to State institutions: ruptural, interstitial and symbiotic. These categories do not represent heterogeneous positions regarding the ultimate goal of a social emancipatory movement ("where we want to go"), but they rather identify differentiated strategies for achieving these goals ("how to get there"). Different segments of the local food movement can therefore be differentiated according to the nature of the collective strategies they propose and adopt for setting in motion the desired transformation of the food system.

'Ruptural transformations' (or "smash the State strategy", Wright 2006: 122) aim at creating new institution of social empowerment through a complete break with existing forms of social structures, based on the idea that confrontation and political struggle will create a radical disjuncture with existing institutions. Ruptural transformations are not necessarily confined to revolutions. They may be partial, rather than total, as they can involve a subset of institutions rather than the foundations of a social system. "The unifying idea is of sharp discontinuity and rapid change, rather than metamorphosis over an extended period of time" (Wright 2006: 122).

'Interstitial transformations' ("ignore the State strategy") initiatives have in common the idea of building alternative institutions and deliberately fostering new forms of social relations that embody emancipatory ideals through direct action. As also theorized in the MLP, interstitial transformations operate in niches at the margins of capitalist society, where they are often not perceived as an immediate threat to dominant classes and elites. Yet, cumulatively, such initiatives create enlarged spaces for non-commodified, non-capitalist, 'diverse' (Gibson-Graham, 2006) economic and social relations, which "can not only make a real difference in people's lives, but potentially constitute a key component of enlarging the transformative scope for social empowerment in the society as a whole" (Wright 2006:122).

'Symbiotic transformations' ("use the State strategy") "involve strategies in which extending and deepening the institutional forms of popular social empowerment also solves certain practical problems faced by dominant classes and elites" (Wright 2006: 122). Symbiotic transformations have a contradictory character, often taking advantage of a tension between the short- and long-term effects of institutional change. In the short term, symbiotic forms of social empowerment are in the interests of elites and dominant classes; in the long term they can shift the balance of power towards broader social empowerment. It may be also thought that advances in bottom-up social empowerment will be most stable and defensible when social empowerment 
helps solve also real problems faced by capitalists and other elites. Positive compromises between different interests may be realized (producers and consumers; rural and urban economies) through collaborative problem-solving processes. Examples of symbiotic transformative processes may range from civic renewal movements to food councils, watershed councils and territorial development pacts.

Local food movements seem to consider interstitial and symbiotic strategies as the most appropriate to their emancipatory project, instead of ruptural or oppositional strategies. ${ }^{5}$ It would also appear that the choice of the transformation strategy is processional, i.e. it changes according to the different stages of the movement life-cycle but also according to different contextual contingencies. For example, the Fair Trade and organic movements were considered to operate according to an interstitial strategy in their early stages of development, but the consolidation of their initiatives and the strengthening of their economic realities were accompanied by a switch to a symbiotic strategy (Renard 1999).

Interstitial activities have in common the strategy of building alternative institutions and fostering new forms of social relations through direct action rather than through the support of the State. This approach seems to characterize large portions of the local food movement. Among the Italian alternative food movement (Fonte and Cucco 2015), the most prominent proponent of an interstitial strategy are Solidarity Purchasing Groups, which look with suspicion to State interference in their initiatives. At the same time, other segments of Italian alternative agriculture like Slow Food, the Campagna Amica Farmers' Markets network and the Italian Association of Organic Agriculture seems to opt for a symbiotic strategy.

Food councils and public procurement policies intended to promote local, organic, healthy food also adopt a symbiotic strategy in pursuing the transformation of the food system, although the symbiotic relationship is generally established with the local rather than with the central State. Municipal authorities and representatives of different local interests collaborate with civil society organizations in designing and implementing policies that foster the interests of local agriculture and local communities of food. By working with local institutions, especially at the municipal or regional level, CFNs are implementing initiatives that better consolidate new experiences of food democracy and food justice. In all these initiatives the role of local actors is important also in terms of agency. The contribution of CFNs has been particularly relevant in this regard, since they have stressed the transformative potential of the 'consumer' intended not as the neoliberal agent operating to make markets work better, but as the 'ecological citizen' ready to assume responsibility for local and global problems and to organize collective democratic action in order to advance toward a solution.

\section{DISCUSSION: THE NEED FOR NEW GOVERNANCE MODELS}

The capacity of local food to determine a paradigm shift in the global food economy may be undermined by the fragmentation of the local food movement initiatives. The capacity to coordinate actions and to create new spaces of governance and regulation may instead bring to full expression not only their capacity to innovate and radically transform systems of food provision and consumption, but also heighten their potential to create

5 This does not want to exclude that the objective of the local food movement is 'ruptural', i.e. wants to create a radical disjuncture with existing institutions, but only to indicate that the adopted strategies are not openly oppositional. 
spaces for new forms of knowledge creation, sharing and social learning on themes related to sustainability and democracy.

The concept of food-shed or food hub is discussed in the literature as the proper space where to ground the localized food system to overcome the fragmentations of the many local initiatives while maintaining placeembeddedness. But still, a system of multi-scalar governance is needed, in order to bolster a paradigm shift toward sustainability and food security. Two new models seem to emerge in the debate on this topic: one is reflexive governance, as described by Marsden (2013), based on the results of research on the sociology of knowledge production in a context of uncertainty and especially on the 'mode- 2 ' of knowledge production postulated by Nowotny et al. (2001) or on the notion of post-normal science (Funtowicz and Ravetz, 1993). It promotes cognitive procedures designed to favour feedbacks on multiple regulatory frameworks, and flexible arrangements of actors from different levels and different epistemic backgrounds, who reflect a plurality of contexts and are ready to scrutinize and reconsider their own assumptions and favour the integration of cognitive and normative beliefs.

The second model is the Empowered Participative Governance (EPG) (Fung and Wright 2003), derived from the results of political science studies on deliberative forms of democracies. The EPG relies on the capacities of local people - the only ones to possess local knowledge- to solve local problems through reasoned deliberation procedures. Mobilized forms of power of disadvantaged groups in a decision-making setting are meant to engender collaborative, deliberative problem-solving. The collaborative forms of decision-making are different from adversarial forms: in the last case interest groups seek to maximize their interests, while in the former the central effort is to solve problems, to discover the broader commonalities of interests.

Two points are important in this model: (1) it is a State-centred model: local units are not autonomous, but linked to each other and to superior levels in order to allocate resources, solve common cross-border problems, diffuse innovation and learning. (2) Institutional mechanisms are in action to reduce or neutralize the power advantage of most powerful actors. These institutional mechanisms must be based on what Fung and Wright (2003) call 'the collaborative countervailing power' that, in the case of the food economy, may arise from locally organized groups like GAS or CSA; from policies that open spaces to form participative local governance as in the case of Food Councils; or from local branches of national traditional organizations like unions or environmental organizations. The reorganization of formal state institutions may be a stimulus to democratic engagement in civil society and form a virtuous circle of reciprocal reinforcement between civic engagement and democracy.

The contributions of LFMs and CFNs to a new empowering co-experimentation of food politics may be very important in order to express their full innovative potential and may call for a stricter alliance and coordination between LFMs, the Food Sovereignty movement and other new social movements.

\section{CONCLUSIONS}

Differently from the oppositional movements of the Fordist era, which relied on ruptural strategies aimed at 'smashing the state', local food initiatives and Civic Food Networks adopt mainly interstitial and symbiotic 
strategies with the aim of building alternative practices and social relations in the food economies. For this reason, local food movements have attracted critiques of being functional to a neoliberal politics of discarding the State (Guthman 2007).

When viewed through the lens of transition theories, the strategies adopted by local movements appear however to have a significant, even if not fully developed, transformative potential. The multi-level perspective and social practice theories indicate that the development of innovative niches and the construction of new consumption practices may lead to the reconfiguration of the system in direction of sustainability. The Real Utopias lens suggests that innovative local food niches are mobilizing non-ruptural strategies in the service of a social emancipatory vision. In so doing, local food initiatives are creating new, enlarged spaces for noncapitalist or post-capitalist economies that not only pre-figure how the global food system could be transformed in the direction of sustainability, empowerment and social justice, but effectively may constitute the basis of learning and experimentation necessary to go in that direction. A new model of governance, based on principles of social empowerment, may help to overcome the fragmentation that inevitably characterize local food initiatives, while at the same time coordinating the transformative efforts for the full expression of their innovative potential toward the construction of a more just and sustainable food economy.

\section{ACKNOWLEDGMENTS}

We want to thank the organisers for inviting us to the very stimulating seminar on the changing role of food in contemporary European society, held in Budapest on June 16-17, 2015, that led to this paper and the two anonymous referees who provided us with insightful comments. 


\section{REFERENCES}

Altieri, M. A. - Nicholls, C.I. (2010) Agroecologia: potenciando la agricultura campesina para reverir el hambre y la inseguridad alimentarias en el mundo. Revista de Economia Critica, 10, 62-74.

Altieri, M.A. - Toledo, V. M. (2011) The agroecological revolution in Latin America. Journal of Peasant Studies, 38, 587-612.

Blythman, J. (2005) Organic food is not necessarily the automatic choice for the ethical consumer. The Ecologist, 17 June 2005.

Born, B. V. M. - Purcell, M. (2006) Avoiding the local trap: scale and food system in planning research. Journal of Planning Education and Research, 26, 195-207.

Brunori, G. - Rossi, A. - Guidi F. (2012) On the new social relations around and beyond food. Analysing consumers' role and action in Gruppi di Acquisto Solidale (Solidarity Purchasing Groups). Sociologia Ruralis, 52(1), 1-30.

Buck, D. - Getz, C. - Guthman J. (1997) From farm to table: the organic vegetable commodity chain of northern California. Sociologia Ruralis, 37(1), 1-20.

Crivitis, M. - Paredis, E. (2013) Designing an explanatory practice framework: Local food systems as a case, Journal of Consumer Culture, 13(3), 306-336.

Darnhofer, I. - Lindenthal, T. - Bartel-Kratochvil, R. - Zollitsch, W. (2010) Conventionalisation of organic farming practices: from structural criteria towards an assessment based on organic principles. A review. Agronomy for Sustainable Development, Springer Verlag, 30 (1), <10.1051/agro/2009011>. <hal-00886488>. Available at https://hal.archives-ouvertes.fr/hal-00886488/document . Accessed on November 18, 2015.

DeLind, L. B. (2011) Are local food and the local food movement taking us where we want to go? Or are we hitching our wagons to the wrong stars? Agriculture and Human Values, 28, 273-283.

Demaria, F. - Schneider, F. - Sekulova, F. - Martinez-Alier, J. (2013) What is Degrowth? From an activist slogan to a social movement, Environmental Values, 22, 191-215.

FAO (2015) The State of Food and Agriculture. Rome.

Fonte, M. (2013a) Food consumption as social practice: Solidarity Purchasing groups in Rome. Journal of Rural Studies, 32, $230-239$.

Fonte, M. (2013b) Reflexive Localism: Toward a Theoretical Foundation of an Integrative Food Politics. International Journal of Sociology of Agriculture and Food, 20, 3, 397-402.

Fonte, M. (2010) Introduction: food relocalisation and knowledge dynamics for sustainability in rural areas. In Fonte, M. - Papadopoulos, A. G. (eds.) Naming Food After Places, Food Relocalisation and Knowledge Dynamics in Rural Development. Ashgate.

Fonte, M. (2008) Knowledge, Food and Place. A way of producing, a way of knowing. Sociologia Ruralis, 48 (3): $220-222$.

Fonte, M. - Cucco, I. (2015) The Political economy of Alternative Agriculture in Italy. In Bonanno, A. - Busch, L. Handbook of the International Political Economy of Agriculture and Food. Cheltenham, UK: Elgar Publishing, 264-294.

Friedmann, H. (1992) Distance and durability: Shaky foundations of the world food economy. Third World Quarterly, 13(2), 371-383.

Fung A. - E.O. Wright (eds.) (2003) Deepening democracy. London: Verso.

Funtowicz, S. - Ravetz, J. R. (1993) Science for the Post-Normal Age. Futures, 25, 735-755.

Garnett, T. (2007) Animal Feed, Livestock and Greenhouse Gas Emissions: What are the Issues? Paper presented to the Society of Animal Feed Technologists, Coventry, 25 January 2007.

Geels, F. W. (2005) Processes and patterns in transitions and system innovations: Refining the co-evolutionary multi-level perspective. Technological forecasting and social change, 72(6): 681-696.

Geels, F. W. - Schott, J. (2007) Typology of socio-technical transition pathways. Research Policy, 36, 399-417.

Geels, F. W. - McMeekin, A. - Mylan J. - Southerton, D. (2015) A critical appraisal of Sustainable Consumption and Production research: The reformist, revolutionary and reconfiguration positions. Global Environmental Change, 34, 1-12.

Gibson-Graham, J. K. (2006) A postcapitalist politics. University of Minnesota Press.

Goodman, D. - DuPuis, E. M. - Goodman, M. K. (2012) Alternative Food Networks. Abingdon, UK: Routledge.

Guthman, J. (2003) The trouble with 'organic lite' in California: a rejoinder to the 'conventionalisation' debate. Sociologia Ruralis, 44(3), 301-316.

Guthman, J. (2007) Why I am fed up with Michael Pollan et al. Agriculture and Human Values, 24, 261-264.

Halkier, B. (2009) A practice theoretical perspective on everyday dealings with environmental challenges of food consumption. Anthropology of Food (Online), S5jSeptember 2009. URL: http://aof.revues.org/6405://www.uvm.edu/vtvegandberry/factsheets/buylocal.html. 
Harris, E. M. (2009) Neoliberal subjectivities or a politics of the possible? Reading for difference in alternative food networks, Area $41(1), 55-63$.

Heise, U. K. (2008) Sense of Place and Sense of Planet: The Environmental Imagination of the Global. USA: OUP.

Hinrichs, C. (2000) Embeddedness and local food systems: notes on two types of direct agricultural market. Journal of Rural Studies, 16:295-303.

Hinrichs, C. (2014) Transitions to sustainability: a change in thinking about food systems change? Agriculture and Human Values, http://dx.doi.org/10.1007/s10460-014-9479-5.

Hinrichs, C. (2015) Fixing food with ideas of "local" and "place". Journal of Environmental Studies and Sciences. http://dx.doi.org/10.1007/s13412-015-0266-4.

Jackson, T. (2009) Prosperity without growth. Sustainable Development Commission. Available at http://www.nfft.hu/ dynamic/20090522_pwg_summary_eng.pdf. Accessed on November 18, 2015

Kloppenburg, J. R. - Hendrickson, J. - Stevenson, G. W. (1996) Coming into the foodshed. Agriculture and Human Values, 13:33-42

Lipton, M. (1977) Why Poor People Stay Poor: Urban Bias in World Development. Maurice Temple Smith Ltd.

Lyson, T. A. (2004) Civic Agriculture: Reconnecting Farm, Food and Community. University Press of New England.

Marsden, T. K. - Banks, J. - Bristow, G. (2000) Food supply chain approaches: exploring their role in rural development. Sociologia Ruralis, 40, 424-438.

Marsden, T. (2013) From post-productivism to reflexive governance: contested transitions in securing more sustainable food futures, Journal of Rural Studies 29: 123-134.

Massey, D. (1994) Space, Place and Gender. Polity Press.

McMichael, P. (2014) Historicizing food sovereignty. The Journal of Peasant Studies, 41(6), 933-957.

Morgan, K. - Marsden, T. - Murdoch, J. (2006) Worlds of food: place, power and provenance in the food chain. Oxford UK: Oxford University Press.

Moore, O. (2006) Farmers' markets, and what they say about the perpetual post-organic movement in Ireland. In Holt, G. - Reed, M. (eds.) Sociological Perspectives of Organic Agriculture: From Pioneer to Policy, Wallingford: CABi Publishing, 18-36.

Nowotny, H. - Scott, P. - Gibbons, M. (2001) Re-thinking Science. Knowledge and the Public in an Era of Uncertainty. Cambridge: Polity Press.

Patel, R. (2007) Stuffed and Starved: Markets, Power and the Hidden Battle for the World's Food System. UK: Portobello.

Pirog, R. - Rasmussen, R. (2008) Food, Fuel and the Future: Consumer Perceptions of Local Food, Food Safety and Climate Change in the Context of Rising Prices. Ames, lowa, USA: Leopold Center for Sustainable Agriculture. Accessed on November 18, 2015.

Pirog, R. - Van Pelt, T. - Enshayan, K. - Cook, E. (2001) Food, Fuel, and Freeways: An lowa Perspective on How Far Food Travels, Fuel Usage, and Greenhouse Gas Emissions. Leopold Center for Sustainable Agriculture. Accessed on November 18, 2015.

Pirog, R. - Benjamin, A. (2003) Checking the Food Odometer: Comparing. Food Miles for Local Versus Conventional Produce Sales to lowa Institutions, Leopold Center for Sustainable Agriculture. Available at: www.leopold.iastate.edu. Accessed on November 18, 2015.

Polany, K. (1944) The Great Transformation. The political and economic origins of our time. NY: Farrar \& Rinehart.

Reed, M. (2010) Rebels for the Soil: The Rise of the Global Organic Food and Farming Movement. Earthscan, London, UK.

Renard, M. C. (1999) The Interstices of Globalization: The Example of Fair Coffee. Sociologia Ruralis 39(4), 484-500.

Renting, H. - Marsden, T. - Banks, J. (2003) Understanding alternative food networks: exploring the role of short food supply chains in rural development. Environment and Planning A, (35): 393-411.

Renting, H. - Schermer, M. - Rossi, A. (2012) Building Food Democracy: Exploring Civic Food Networks and Newly Emerging Forms of Food Citizenship. International Journal of Sociology of Agriculture and Food, 19 (3).

Reckwitz, A. (2002) Towards a theory of social practices. A development in culturalist theorizing. European. Journal of Social Theory, 5 , 243-263.

Rifkin, J. (2014) The zero marginal cost society. Palgrave Macmillan.

Schatzki, T. (1996) Social Practices. A Wittgenstein Approach to Human Activity and the Social. Cambridge: Cambridge University Press.

Severson, K. (2009) When 'local' makes it big. The New York Times [online] May 13: [D-1]. Available at http://www.nytimes. com/2009/05/13/dining/13local.html? pagewanted=all\&_r=0 (accessed October 15, 2015). 
Shove, E. - Pantzar, M. - Watson, M. - (2012) The Dynamics of Social Practice. Everyday Life and How It Changes. London, UK: Sage.

Smith, J. - Jehlička, P. (2013) Quiet sustainability: Fertile lessons from Europe's productive gardeners, Journal of Rural Studies, 32 , 148-157.

Steel, C. (2013) Hungry City: How Food Shapes Our Lives. London.

Strassen, S. (2003) Commodifying Everything: Relationships of the Market. London: Routledge.

Tukker, A. - Huppes, G. - Guinée, J. - Heijungs, R. - de Koning, A. - van Oers, L. - Suh, S. - Geerken, T. - Van Holderbeke, M. - Jansen, B. - Nielsen P. (2006) Analysis of the life cycle environmental impacts related to the final consumption of the EU-25. Main report, European Commission, Joint Research Centre. Available online at http://ec.europa.eu/environment/ipp/pdf/eipro_report.pdf. Accessed August 4th 2015.

Warde, A. (2005) Consumption and theory of practice. Journal of Consumer Culture, 5, 131-153.

Wright, E. O. (2006) Compass Points. Towards a Socialist Alternative. New Left Review, 41: 93-124.

Wright, E. O. (2010) Envisioning Real Utopias. London: Verso. 